\title{
Effect of Nitrogen and Bradyrhizobium on Growth and Yield of Mungbean
}

\author{
Md. Elias Hossain ${ }^{1}$, Imtiaz Faruk Chowdhury ${ }^{2}$, Md. Hasanuzzaman ${ }^{3}$, Sujan Mazumder $^{4}$, Md. \\ Abdul Matin ${ }^{4 *}$ and Rahima Jerin ${ }^{4}$ \\ Dept. of Agricultural Chemistry, Sher-E-Bangla Agricultural University (SAU), Dhaka ${ }^{1}$ \\ Lecturer, Dept. of Agronomy, SAU, Dhaka ${ }^{2}$ \\ Assistant Professor, Dept. of Agronomy, SAU, Dhaka ${ }^{3}$ \\ Dept. of Agronomy, SAU, Dhaka, Bangladesh ${ }^{4}$ \\ Corresponding author* email: krisibid.matin@gmail.com
}

\begin{abstract}
The objective of the present study was to investigate the comparative roles of nitrogen $(50 \mathrm{~kg}$ $\mathrm{ha}^{-1}$ ) and inoculums Bradyrhizobium $\left(1.5 \mathrm{~kg} \mathrm{ha}^{-1}\right)$ in improving the yield of two mungbean varieties (BARI mung-5 and BARI mung-6). The experiment was carried out during the period from April 2011 to July 2011 at the Sher-e-Bangla Agricultural University (SAU) Farm, Dhaka. The experiment was laid out in Randomized Complete Block Design (RCBD) with four replications and plot size was $8 \mathrm{~m}^{2}$ with $30 \mathrm{~cm}$ line spacing. The Bradyrhizobium strain BARI RVr-403 was used for the experiment. The recommended dose of TSP, MOP and Gypsum were applied in each plot. BARI Mung-6 performed higher stover and seed yield than BARI Mung-5. Bradyrhizobium inoculation significantly increased 1000-seed weight, pods plant ${ }^{-1}$, seeds pod $^{-1}$, stover and seed yield. BARI Mung-6 with Bradyrhizobium inoculation recorded the highest seed and stover yield compared to other treatment combinations. Non-inoculated BARI Mung-5 gave the lowest yield.
\end{abstract}

Keywords: Mungbean, Biofertilizer, Nitrogenous fertilizer and Yield

\section{Introduction}

Mungbean (Vigna radiata L. Wilezek) cultivation has been declining due to low yield and less economic return whereas it is an important pulse crop in Bangladesh. It is widely grown in Bangladesh as pulse crops for human consumption, animal fodder as well as soil fertility building purpose. Costly and environmentally risky chemical fertilizers cause serious and continuous problem for increasing mungbean production in developing countries including Bangladesh. These problems are likely to become serious in future. Biological Nitrogen Fixation (BNF) resulting from symbiosis between legume crops and root nodule bacterium Bradyrhizobium can ameliorate these problems by reducing the chemical $\mathrm{N}$-fertilizer input required to ensure productivity. As a legume, mungbean is capable of utilizing atmospheric nitrogen through symbiotic association with Bradyrhizobium sp. (Vigna) and thereby can meet the requirement of the element. Inoculation of mungbean with effective Bradyrhizobium inoculant is necessary for soils where the organisms are ineffective or where they are absent or scarce (Vincent, 1970).

Bradyrhizobium strains are present in all soils of Bangladesh but they may not be equally effective in nodulation and $\mathrm{N}$-fixation. In this situation, inoculation can meet the challenge by providing superior strains in the soil, so that the most effective nodulation and nitrogen fixation are obtained. Thus it was thought that there is a scope for utilizing the effective bradyrhizobial strains for obtaining more yield 
of mungbean under field conditions which may play vital role in improving soil environment and agricultural sustainability.

To reduce the production cost and to fulfill the demand, more pulse production could be achieved through seed inoculation with Bradyrhizobium strains which is known to increase biological nitrogen fixation. Bradyrhizobium inoculation increased mungbean seed yield from $4.3 \%$ to $16.2 \%$ (Vaishya et al., 1983). In Bangladesh, inoculation with Bradyrhizobium increased 25\% dry matter production, $28 \%$ grain yield and 21\% hay yield over non-inoculated. (Bhuiyan and Mian, 2007). Maximum yields were obtained when fertilizers applied together with Bradyrhizobium inocula.

\section{Materials and Method}

\section{Genetic Materials and Experimental Site}

The experiment was carried out during the period from April 2011 to July 2011 to finding out the yield performance of two mungbean with nitrogenous and bio fertilizers at the Sher-e-Bangla Agricultural University (SAU) Farm, Dhaka. The experimental site was situated at $23^{\circ} 77^{\prime}$ North Latitude and $90^{\circ} 30^{\prime}$ East Longitude. The area belongs to the Agro-ecological Zone (AEZ- 28): Madhupur Tract. The soil was silty-loam containing $1.05 \%$ organic matters, $0.08 \% \mathrm{~N}$ and soil $\mathrm{pH}$ was 6.9, available $\mathrm{P}(\mathrm{ppm}) 12.78$, available $\mathrm{K}$ (ppm) 43.29, available $\mathrm{S}$ (ppm) 23.47, available B (ppm) .06 . The experiment comprised of two mungbean varieties (BARI mung-5 and BARI mung-6) fertilizers viz., control (without $\mathrm{N}$ and inoculum), urea $\left(50 \mathrm{~N} \mathrm{~kg} \mathrm{ha}^{-1}\right)$ and inoculated (Bradyrhizobium inoculum $1.5 \mathrm{~kg} \mathrm{ha}^{-1}$.

\section{Experimental Design and Crop Husbandry}

The experiment was laid out in Randomized Complete Block Design (RCBD) with four replications. The lands were fertilized with 22, 42, 20 and $5 \mathrm{~kg} \mathrm{ha}^{-1}$ of $\mathrm{P}, \mathrm{K}, \mathrm{S}$ and $\mathrm{Zn}$ in the form of Triple Superphosphate, Muriate of Potash, Gypsum and Zinc Sulphate, respectively. Nitrogen was applied as urea according to the treatments.

The peat soil was collected from Gopalgonj and the $\mathrm{pH}$ was adjusted 4.5 to 6.8 by adding $\mathrm{CaCO}_{3}$ for inoculation. Fifty grams of amended peat having 8 per cent moisture was taken in each polyethylene bag and the bags were sealed up. Then they were sterilized by autoclaving for three consecutive days for one hour each day. The sealed peat was ready for inoculation. The bradyrhizobial inoculant was prepared in the Soil Microbiology Laboratory of BARI using the broth culture. The Bradyrhizobium strain (BARI RVr-402) was collected from the stock culture of the laboratory. Yeast extract mannitol broth was prepared in a $250 \mathrm{ml}$ Erlenmeyer flask. The liquid medium was sterilized for 30 minutes at $121^{\circ} \mathrm{C}$ at 15 PSI. The medium was kept for cooling. After cooling, a small portion of Bradyrhizobium culture was aseptically transferred from agar slant to the liquid medium in the flask with the help of a sterile inoculation needle. The flask was then placed in the shaker at $28^{\circ} \mathrm{C}$ under $120 \mathrm{rpm}$ to enhance bradyrhizobial growth. After 6-7 days, the medium in the flask showed dense growth and then the broth culture was taken out from the shaker. From this ready broth, $20 \mathrm{ml}$ were taken out by sterile syringe and injected into the polyethylene packet having the sterile peat. Finally, the moisture percent of the packet was adjusted to 50 percent. The inoculated packets were then incubated at $28^{\circ} \mathrm{C}$ for two weeks to make them ready for seed inoculation. Viability count of Bradyrhizobia in the inoculant was made one day before injecting the peat following plate count method (Vincent, 1970). The average number of Bradyrhizobia was approximately above $10^{8}$ cells $\mathrm{g}^{-1}$ in the inoculant. Inoculation was 
done just before sowing. Healthy Mungbean seeds @ $25 \mathrm{~g}$ for each plot were taken into polyethylene bags separately and $1 \mathrm{ml}$ of the sticker solution (4\% gum acacia solution) was added to each bag with sterilized pipettes. It was followed by addition of $1.25 \mathrm{~g}$ of the desired peat based Bradyrhizobium inoculant to each polyethylene bag and mixed thoroughly for uniform distribution and good adherence of inoculant on the surface of each seed. Mungbean was sown on 27 April 2011. Healthy seeds of Mungbean@35 kg ha ${ }^{-1}$ were sown by hand as uniformly as possible in furrows. Different polyethylene bags were used for different treatments and the uninoculated seeds were sown first to avoid the risk of contamination.

Seeds were sown in the afternoon and immediately covered with soil to avoid sunlight. Each plot was measured $2.4 \mathrm{~m}$ x $2 \mathrm{~m}$. Line to line distance was $30 \mathrm{~cm}$.

\section{Data Recording, Measurements and Analysis}

The observation on grain yield and stover yield was recorded. The collected data were analyzed statistically using MSTST c computer package (Freed, 1992) and mean separation was done by Duncan's Multiple Range Test (DMRT) at 5\% level of significance. The correlation co-efficient and regression analysis were done for different variables wherever needed using Microsoft EXCEL programme 2007.

\section{Results and Discussion}

\section{Effect of Variety on Yield}

There was significant variation in seed yield and stover yield of the two varieties of Mungbean (Figure 1). The variety BARI Mung-6 recorded a seed yield of $836 \mathrm{~kg} \mathrm{ha}^{-1}$ while it was $770 \mathrm{~kg} \mathrm{ha}^{-1}$ for the variety BARI Mung-5. In modern varieties, the reasons for obtaining higher seed yield might be due to high dry matter accumulation, more pods plant $^{-1}$, seeds $\operatorname{pod}^{-1}$ and 1000 -seed weight as compared to local variety. The present result is in agreement with Samanta et al. (1999), Tickoo et al. (2006), Navgire et al. (2001) and Hossain and Solaiman (2004) who reported that varieties of Mungbean differed significantly in seed yield.

The higher stover yield (1985 $\mathrm{kg} \mathrm{ha}^{-1}$ ) was produced by the BARI Mung-6 which was superior to BARI Mung-5 (1858 kg ha-1). Obtaining higher stover yield might be due to high photosynthesis and dry matter accumulation in modern varieties compare to local varieties. Hossain and Solaiman (2004) compared six Mungbean (BARI Mung-2, BARI Mung-3, BARI Mung-4, BARI Mung-5, BINA Moog-2 and BU Mung-1) and obtained higher stover yield from BARI Mung-4 than other. Bhuiyan and Mian (2007) reported that among five Mungbean varieties BARI Mung-2 produced the highest stover yield in Mungbean. Ara (2004) gave significantly higher stover yield in BARI Mung-3 than BARI Mung-4. 


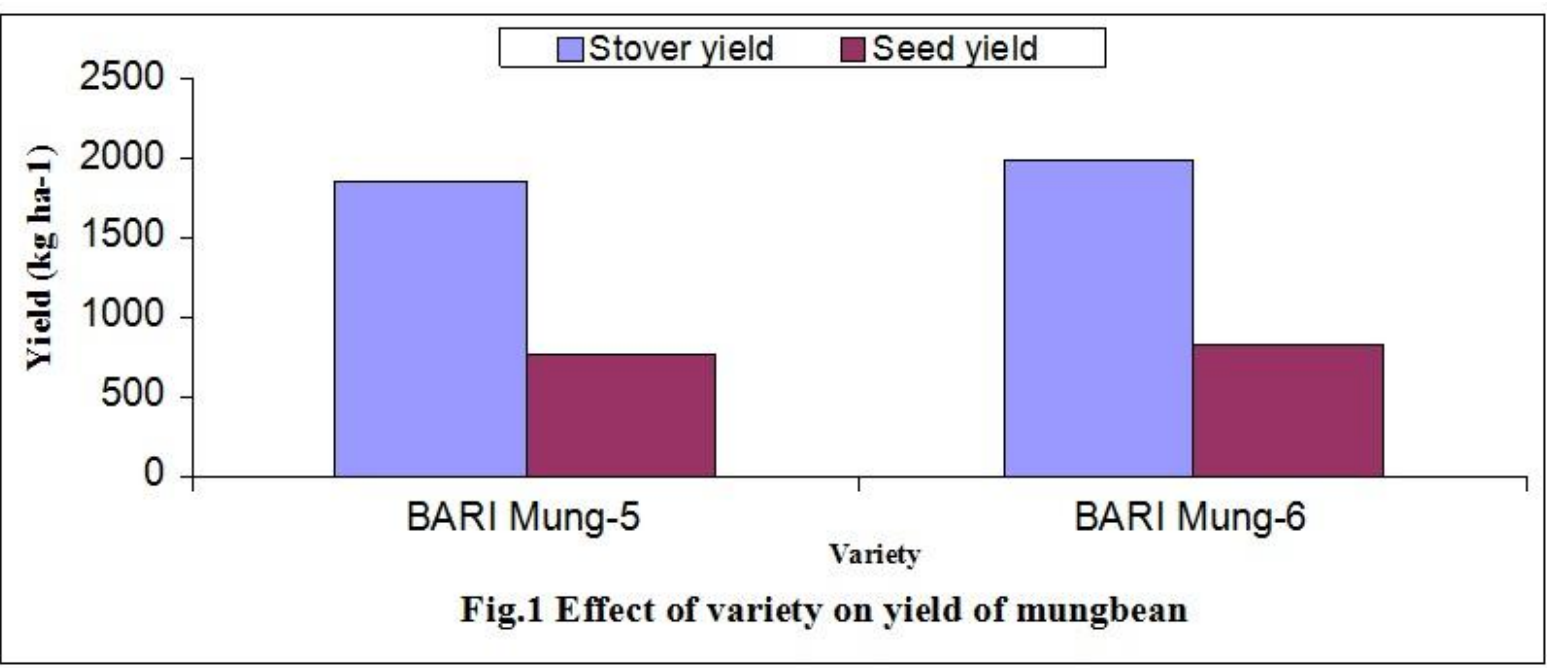

\section{Effect of Fertilizer on Yield}

The nitrogen and Bradyrhizobium inoculants showed significant increase in seed yield and stover yield of Mungbean (Fig. 2). The Bradyrhizobium inoculated plants showed the highest seed yield (876 $\left.\mathrm{kg} \mathrm{ha}^{-1}\right)$ which was statistically superior to other treatments. The lowest seed yield $\left(716 \mathrm{~kg} \mathrm{ha}^{-1}\right)$ was showed in non-inoculated plant. Bradyrhizobium fix more atmospheric nitrogen $\left(\mathrm{N}_{2}\right)$ to the soil into ammonia $\left(\mathrm{NH}_{3}\right)$ or ammonium $\left(\mathrm{NH}_{4}{ }^{+}\right)$through the formation of root nodule which are readily available to the plant. Plant uptakes more available nitrogen for their growth and development. Readily available nitrogen helps to increase more photosynthesis and dry matter accumulation as well as increase the plant height, leaf area index, branches and enhance biomass of root and shoot. Ultimately it increases the pod length, seeds pod-1, 1000-grain weight of Mungbean and performed more seed yield. Sharma and Khurana (1997) stated that single strain and multi-strain Rhizobium inoculants increased the grain yield by $10.4 \%$ and $19.3 \%$ over uninoculated control, respectively. Bhattacharya and Pal (2001) reported that inoculation of Rhizobium influenced maximum seed yield comparing with control. Bhuiyan and Mian (2007) reported that application of Bradyrhizobium inoculant produced significant effect on seed yields and 27-29\% increase over control of Mungbean. Kumari and Nair (2003) found that yields were more in blackgram and greengram inoculated with Bradyrhizobium.

The highest stover yield of $\left(2290 \mathrm{~kg} \mathrm{ha}^{-1}\right)$ was obtained due to the application of inoculum which was superior to $\mathrm{N}_{50}$ and non-inoculated control $\left(1500 \mathrm{~kg} \mathrm{ha}^{-1}\right)$. Bradyrhizobium take atmospheric nitrogen and fix it into ammonia $\left(\mathrm{NH}_{3}\right)$ or ammonium $\left(\mathrm{NH}_{4}{ }^{+}\right)$through the formation of nodule which uptake the plant for the growth and development. Readily available nitrogen forms helps to increase more photosynthesis and dry matter accumulation as well as the plant height, leaf area index, branches and enhance biomass of root and shoot. As a result increases the stover yield of Mungbean. Bhuiyan and Mian (2007) reported that application of Bradyrhizobium inoculant produced significant effect on stover yields of Mungbean. Nagarajan and Balachandar (2001) reported that seed inoculation of Rhizobium enhanced biomass. Srinivas and Shaik (2002) opined that seed inoculation with Bradyrhizobium culture enhanced haulm yield in Mungbean. Hossain and Solaiman (2004) reported that stover yields increased significantly due to inoculation of the seeds with Rhizobium strains. 


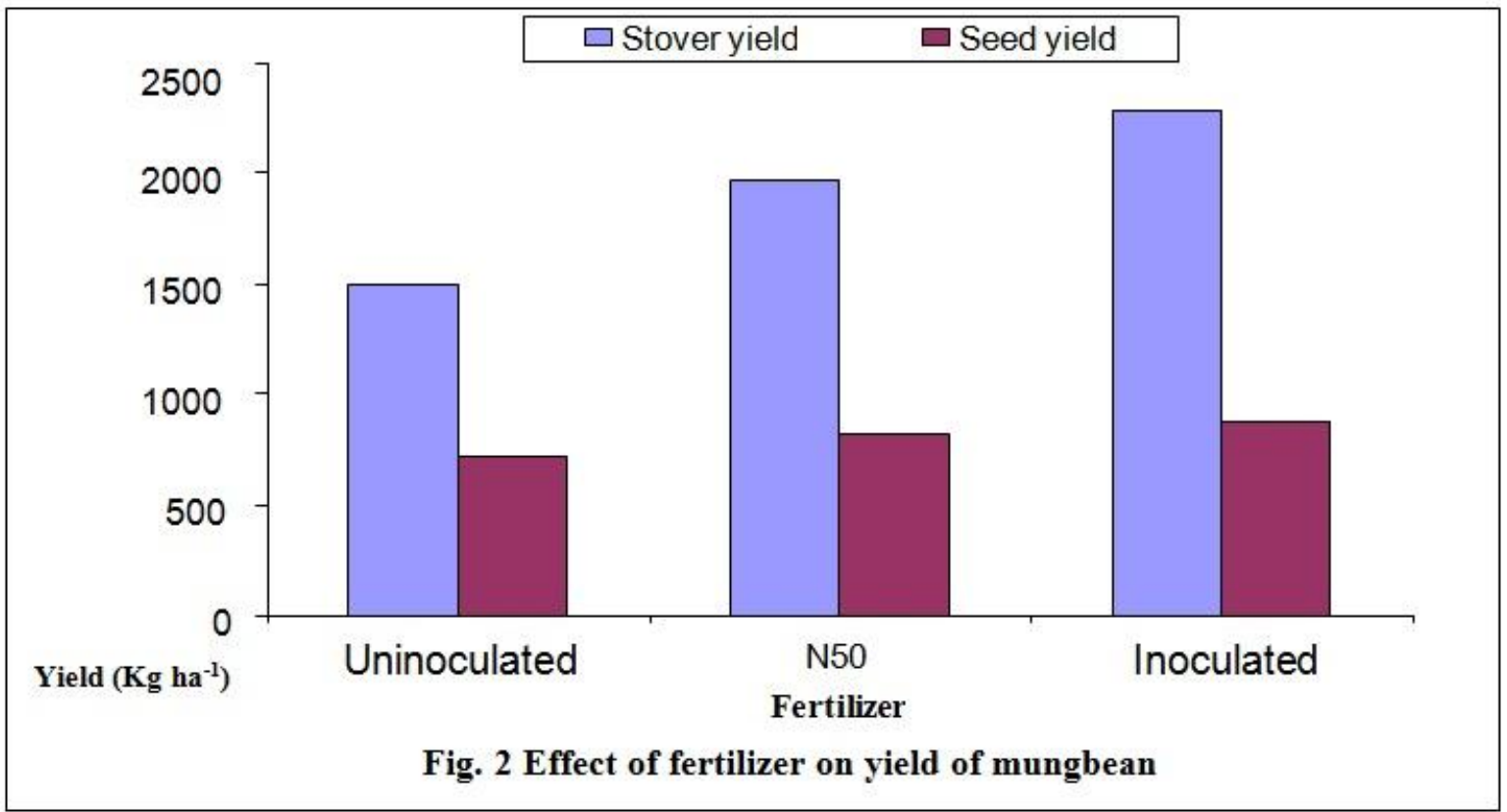

\section{Conclusion}

The Mungbean variety namely BARI Mung-6 performed better in respect to growth and yield (seed and stover) as compared to BARI Mung-5 with the application of nitrogen $\left(50 \mathrm{~kg} \mathrm{ha}^{-1}\right)$ and inoculums Bradyrhizobium $\left(1.5 \mathrm{~kg} \mathrm{ha}^{-1}\right)$. The seed \& stover yield of Mungbean was found increased with the innoculant of Bradyrhizobium. So rhizobial inoculant should be used in Mungbean for higher production of pulses and lower use of chemical fertilizer to meet up the protein requirement.

\section{References}

Ara, N. 2004. Effect of Bradyrhizobium and azotobacter on growth, yield and nutrient uptake of mungbean varieties. M.S. Thesis, Department of Soil Science, Bangladesh Agric. Univ., Mymensingh. pp. 1-70.

Bhattacharyya, J. and Pal, A.Q. 2001. Effect of Rhizobium inoculation, phosphorus and molybdenum on the growth of summer greengram (Vigna radiata L. Wilczek). Indian Agric. 39(2): 173179.

Bhuiyan, M.A.H. and Mian, M.H. 2007. Effects of Bradyrhizobium inoculation on nodulation, biomass production and yield of mungbean. Bangladesh J. Microbiol. 24(2): 95-99.

Freed, R.D. 1992. MSTAT-C. Crop and Soil Science Department, Michigon State University, USA.

Hossain, D. and Solaiman, A.R.M. 2004. Performances of mungbean varieties as affected by Rhizobium inoculants. Bull. Inst. Trop. Agric., Kyushu Univ. 27: 35-43.

Kumari, K.S.M. and Nair, S.K. 2003. Use of acid tolerant strains of Bradyrhizobium sp. for blackgram and greengram. Legume Res. 26(1): 60-62.

Nagaranjan, P and Balachandar, D. 2001. Influence of Rhizobium and organic amendments on nodulation and grain yield of blackgram and greengram in acid soil. Madras Agric. J. 88 (10/12): 703-705.

Navgire, K.D., V.V. Datar, B.V. Asewar and A.L. Dahiwal. 2001. Response of mungbean cultivars to different Rhizobium strains under rainfed conditions. Annals Plant Physiol. 15(2): 134-137. 
Samanta, S.C., Rashid, M.H., Biswas, P. and Hasan, M.A. 1999. Performance of five cultivars of mungbean under different dates of sowing. Bangladesh J. Agril. Res. 24(3): 521-527.

Sharma, P. and Khurana, A.S. 1997. Effect of single and multistrain Rhizobium inoculants on biological nitrogen fixation in summer mungbean, Vigna radiata (L.) Wilczek. Res. and Dev. Reporter. 14(1-2): 8-11.

Srinivas, M. and Shaik, M. 2002. Effect of Rhizobium inoculation and different levels of nitrogen and phosphorus on yield and economics of greengram (Vigna radiata L. Wil.). Crop Res. 24(3): 463-466.

Tickoo, J.L., Chandra, N., Gangaiah, B. and Dikshit, H.K. 2006. Performance of mungbean (Vigna radiata) varieties at different row spacing and nitrogen-phosphorus fertilizer levels. Indian J. Agril. Sci. 76(9): 564-565.

Vaishya, U.K., Gayendragadkar, G.R. and Pandey, R.L. 1983. Effect of Rhizobium inoculation on nodulation and grain yield of mungbean (Vigna radiata L. Wilczek). Indian J. Microbiol. 23: 228-230.

Vincent, J.M. 1970. Root nodule symbiosis with Bradyrhyzobium. In: "Biology of Nitrogen Fixation". Quispel, A (ed). Amer. Elsevier Pub. Co., New York.

\section{Citation For This Article}

M. E. Hossain, I. F. Chowdhury, M. Hasanuzzaman, S. Mazumder, M. A. Matin and R. Jerin, 2014. Performance of Nitrogen and Bradyrhizobium on Growth and Yield of Mungbean. Journal of Bioscience and Agriculture Research 01(02): 79-83. 